\title{
Habitat use by Collared Crescentchest (Melanopareia torquata) in a Cerrado in southeastern Brazil: implications for management
}

\author{
Kanegae, MF. ${ }^{a, c *}$, Levy, G. ${ }^{a}$ and Freitas, SR. ${ }^{b}$ \\ ${ }^{a}$ Laboratório de Ecologia de Aves, Departamento de Ecologia, Instituto de Biociências, \\ Universidade de São Paulo - USP, CEP 05508-090, São Paulo, SP, Brazil \\ bUniversidade Federal do ABC, Rua Santa Adélia, 166, CEP 09210-170, Santo André, SP, Brazil \\ 'Laboratório de Vertebrados, Universidade Federal do Rio de Janeiro - UFRJ, \\ Ilha do Fundão, CEP 21941-590, Rio de Janeiro, RJ, Brazil \\ *e-mail: mieko.kanegae@gmail.com
}

Received October 26, 2011 - Accepted January 25, 2012 - Distributed November 30, 2012

(With 1 figure)

\begin{abstract}
The Collared Crescentchest (Melanopareia torquata) is a small insectivore endemic to the Cerrado. We examine the habitat use of this bird in a preserved Cerrado area in southeastern Brazil. Despite its occurrence in grassland with shrubs, the species used these areas less frequently than expected. The Collared Crescentchest mainly used areas of campo cerrado, but it was not recorded in a disturbed one. The common occurrence of exotic grass (U. decumbens) and cattle grazing may have brought about factors for its occurrence. However, the preference for native grasses may indicate an adverse indirect relationship against its occurence as there is competition between native and exotic grasses in the Cerrado. The presence of the Collared Crescentchest included the highest density of tall shrubs ( $>1 \mathrm{~m})$ and native grasses. Conservation of the species should involve preserved areas of campo cerrado with a dominance of native grasses and tall shrubs.
\end{abstract}

Keywords: habitat use, endemic bird, Cerrado, management.

\section{Uso de habitat pelo tapaculo-de-colarinho (Melanopareia torquata) em um Cerrado do sudeste do Brasil: implicações para o manejo}

\begin{abstract}
Resumo
O tapaculo-de-colarinho (Melanopareia torquata) é uma pequena ave insetívora e endêmica do Cerrado. Examinou-se o uso do habitat dessa ave em uma área de Cerrado preservado no sudeste do Brasil. Apesar de a espécie ser registrada em áreas campestres com arbustos, a sua ocorrência foi menos frequente do que o esperado. O tapaculo-de-colarinho utilizou principalmente áreas de campo cerrado, entretanto não foi registrado em áreas alteradas de campo cerrado. A ocorrência comum de gramíneas exóticas (U. decumbens) e o seu consumo frequente durante o pastoreio do gado podem ter sido fatores agravantes para a ausência da ave nessa área. Contudo, a presença de gramíneas exóticas não inibiu o registro da espécie. O tapaculo-de-colarinho está associado a microhabitat com maior densidade de arbustos altos (>1 m) e gramíneas nativas. Apesar de as gramíneas exóticas não inibirem a presença da espécie, a preferência por gramíneas nativas pode indicar uma relação adversa indireta em razão da competição entre espécies nativas e exóticas do Cerrado. A conservação da espécie envolve a preservação de áreas de campo cerrado com dominância de gramíneas nativas e arbustos altos.
\end{abstract}

Palavras-chave: uso de habitat, ave endêmica, Cerrado, manejo.

\section{Introduction}

The Cerrado is biome rich in bird species, accounting for about $50 \%$ of the total number of bird species in Brazil (856 species). It is the second largest of Brazil's major biomes (Ab'Saber, 1977) and the most threatened savannah in the world due to the high rate of deforestation (Klink and Machado, 2005). A recent survey showed that 55\% of the Cerrado biome has already been cleared or transformed for human use and only $2.2 \%$ is protected in conservation units (Machado et al., 2004).

The Collared Crescentchest (Melanopareia torquata; Melanopareiidae) (body mass 13.5 (males) and 15.6 (females) Kanegae et al., 2010a) is a small insectivorous endemic of the Cerrado (Silva and Bates, 2002). It is a cryptic species moving mainly on the ground, among clumps of grasses 
and shrubs, thus hindering visual detection (pers. obs.). The species is uncommon in open areas, as in grasslands (Ridgely and Tudor, 1994), or more closed ones, as in cerrado sensu stricto (Tubelis and Cavalcanti, 2000). In disturbed areas, it is more frequent in areas of campo cerrado with exotic grasses, occasionally occurring in disturbed areas such as pastures with shrubs (Tubelis and Cavalcanti, 2000).

In the state of São Paulo, the Collared Crescentchest is considered threatened and has been recorded in only two isolated reserves, the EEI (Estação Ecológica de Itirapina) and the Estação Ecológica de Águas de Santa Bárbara (SEMA, 2009). Current studies in EEI show that the population of the species is small from 43 to 76 individuals (Kanegae, 2011) and is probably reducing (Willis, 2004). The major threats for these species in EEI are high frequency of fire (every two years), expansion of exotic grasses and invasion by exotic animals. The species is thought to have low dispersal ability and to be vulnerable to the process of fragmentation (Krabbe and Schulenberg, 2003).

We studied habitat use by one endemic bird of the Cerrado in the EEI. The Collared Crescentchest was chosen because it is easy to detect acoustically and is reducing in this region (Willis, 2004). Our objectives were to evaluate two scales of habitat use: macrohabitat (landscape) and microhabitat (local foraging and use of perch).

\section{Material and Methods}

Study Area - The natural vegetation of the Cerrado in the State of São Paulo originally covered $14 \%$ of the state (SEMA, 1997). Currently, it represents only $0.81 \%$ and occurs in small isolated fragments (Durigan et al., 2007). This study was conducted in the Cerrado of Estação Ecológica de Itirapina (EEI), in the cities of Itirapina and Brotas $\left(22^{\circ} 15^{\prime} \mathrm{S}\right.$ and $\left.47^{\circ} 49^{\prime} \mathrm{W}\right)$ including an area of 2,720 ha (Figure 1). The EEI supports high bird diversity with 231 bird species (Motta-Junior et al., 2008).

The Cerrado Region is characterized by the presence of dry winters and rainy summers and has a complex of habitat types ranging from forests (cerradão) to grasslands (campo sujo and campo limpo). Between these extremes are the intermediate ones, such as cerrado sensu stricto and campo cerrado (Oliveira and Ratter, 2002, Eiten, 1972). We considered the open grasslands campo limpo and campo sujo together in the macrohabitat analysis because they have a similar structure, without trees, and it was not possible to distinguish them in the image generated. More detailed descriptions of Cerrado phytofisiognomies are in Eiten (1972, 1993) and Oliveira \& Ratter (2002).

The altitude of the study area varies between 705 and $750 \mathrm{~m}$ (SEMA, 1997). The climate is humid subtropical with a marked dry season in winter (Köppen, 1948). The mean monthly precipitation in 2006 was $109.9 \mathrm{~mm}$, with a dry season between April and September ranging from 7 to $79 \mathrm{~mm}$ monthly, the rainy season, between October and March, had 119-228 mm monthly. Mean monthly temperatures ranged from $16.2{ }^{\circ} \mathrm{C}$ to $20.1{ }^{\circ} \mathrm{C}$ in the dry season and from $19.5^{\circ} \mathrm{C}$ to $22.3^{\circ} \mathrm{C}$ in the wet season (Gianotti, 1988).

The EEI's Cerrado is one of the priority areas for bird conservation in Brazil (Bencke et al., 2006), due to its richness and high number of threatened species. A recent survey in the EEI reported 231 bird species, of which $38(16.4 \%)$ are on the list of threatened species in the State of São Paulo and/or endemic in the Cerrado (Motta-Junior et al., 2008). The scientific nomenclature we used was proposed by Comitê Brasileiro de Registros Ornitológicos (CBRO, 2011).

There is cattle ranching, housing (a condominium) and Pinus spp. and Eucalyptus spp. plantations as land uses surrounding the reserve. The main threats to the EEI are the expansion of African grasses, Urochloa decumbens and Melinis minutiflora, and exotic trees, including Pinus and Eucalyptus spp. Other disturbance factors are hunters and exotic animals such as cattle, pigs and goats (MottaJunior et al., 2008).

Field procedures - We considered two scales to assess habitat use: macrohabitat (landscape) and microhabitat (use of perches, foraging sites) (Hutto, 1985; Block and Brennan, 1993). The first scale is related to landscape features, such as the different types of habitat (phytofisiognomies) in the Cerrado. The second scale, microhabitat, is related to vegetation characteristics used during vocalization and foraging.

Macrohabitat use - We distributed 134 point samplings arranged in grids of $300 \mathrm{~m}$ apart. Each point was sampled during 10 minutes, when the observer was stationary. From September to December 2006, each point transect was sampled three times, twice in the morning (05:00-09:00 hours) and once in the afternoon (16:00-18:00 hours). Habitat use was obtained by acoustic and visual detection of the bird at the sampling points.

We evaluated six habitat types: cerradão, cerrado sensu stricto, campo cerrado, grasslands, seasonal wetlands and disturbed areas (Table 1). The Collared Crescentchests were recorded during their activities related to vocalization, as territory defense and sexual selection.

The types and percentages of each habitat were obtained by analyzing the Normalized Difference Vegetation Index, based on satellite image of CBERS 2, 17 July 2006, provided by the Instituto de Pesquisas Espaciais (INPE). The spectral signature of each habitat followed Mesquita Junior (1998).

Analysing Macrohabitat use was based on information of use-availability (Garshelis, 2000). The availability of each habitat type and their use was calculated according to Neu et al. (1974) and Canavelli et al. (2003). To determine the possibility of a differential habitat use, we considered the proportions of each habitat type with the confidence interval of Bailey (Canavelli et al., 2003).

Microhabitat use - Radio transmitter monitoring occurred during the breeding season of the species studied, October and November 2007 (Kanegae et al., 2010b). We used 12 radio transmitters, with $3.3 \%$ of the bird weight 
each one (model LB-2, Holohil Systems Ltd); some of them were used twice. The records occurred only on the ground, when the bird was associated to foraging and reproduction activities. The equipment used in monitoring was a LA 12-Q AVMA receiver and a Yagi antenna of three

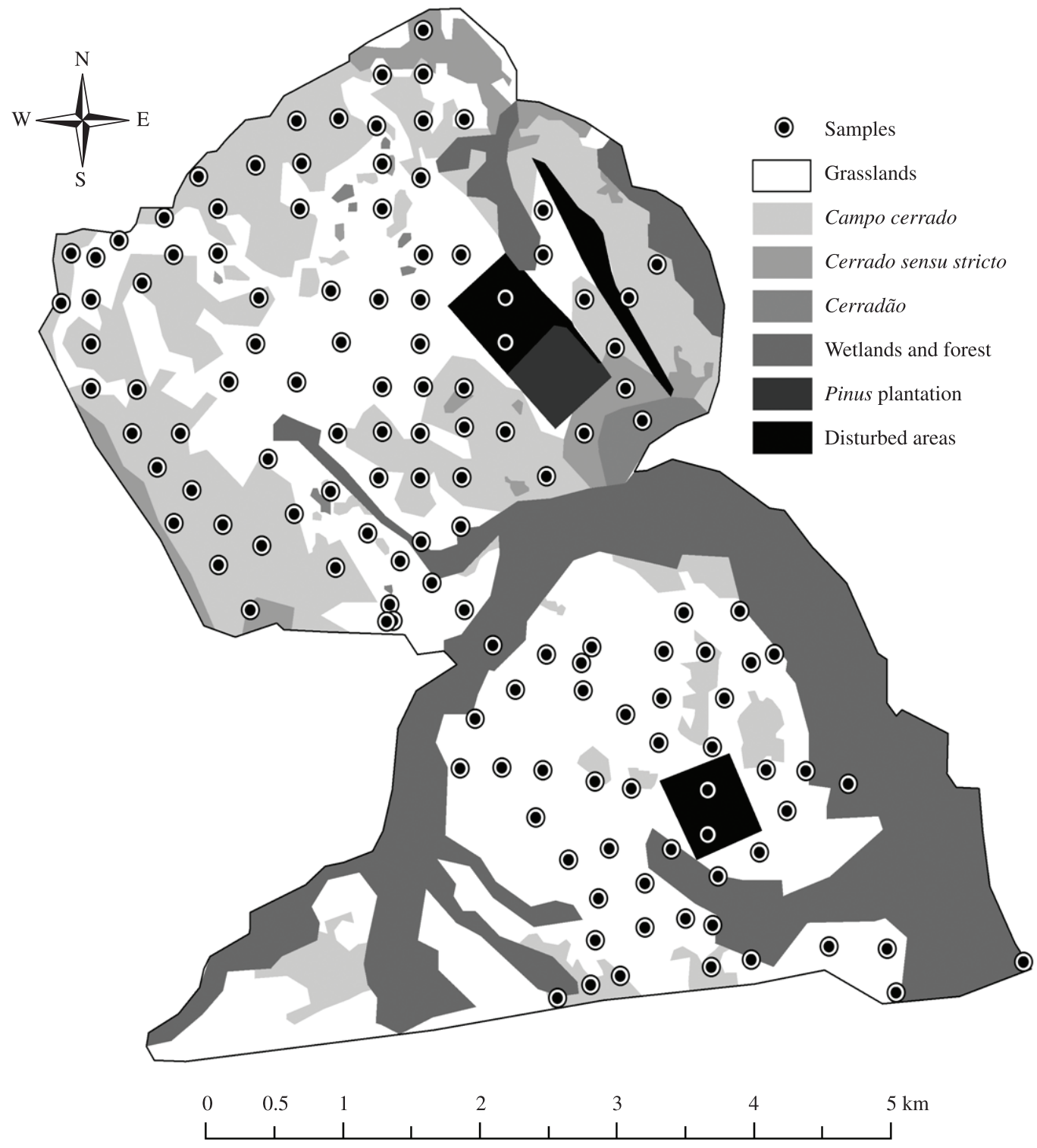

Figure 1. Cerrado phytophisionomies in the Estação Ecológica de Itirapina with total point sampled during 2006.

Table 1. Types of habitat sampled and number of point transects $(\mathrm{N})$ and number of bird records in Estação Ecológica de Itirapina (EEI), between September and December 2006.

\begin{tabular}{lccccc}
\hline \multicolumn{1}{c}{ Habitats } & Area (ha) & \% habitat & N & \% N & Collared crescentchest \\
\hline Seasonal wetland & 420.12 & 17.19 & 24 & 17.91 & 4 \\
Grassland & 1162.28 & 47.57 & 68 & 50.75 & 127 \\
Campo cerrado & 571.44 & 23.39 & 30 & 22.39 & 150 \\
Cerrado sensu stricto & 121.36 & 4.97 & 6 & 4.47 & 0 \\
Cerradão & 52.88 & 2.16 & 2 & 1.49 & 0 \\
Altered area & 115.48 & 4.73 & 4 & 2.99 & 0 \\
Total & 2443.26 & 100.00 & 134 & 100.00 & 281 \\
\hline
\end{tabular}


elements. Details about the radio tracking are described in the chapter on home range size, Kanegae (2009).

Birds were captured from 06:00 to 12:00 hours, and from 16:00 to 18:00, between October and November. Bird captures were, at times, stimulated by playback and occurred using a $12 \times 2 \mathrm{~m}$ mist-net with a nest net of $16 \mathrm{~mm}$. Radio transmitters weighed $0.52 \mathrm{~g}(3.3 \%$ of the bird's weight) and were attached with a ribbon $(0.1 \mathrm{~g})$ using backpack style (Kenward, 2001; Millspaugh and Marzluff, 2001). Males and females were identified genetically by taking blood samples $(0.1 \mathrm{~mL})$ from the jugular vein from the Laboratório de genética e evolução de aves in the Universidade de São Paulo, according to Griffiths et al. (1998).

Radio-transmitter monitoring occurred at intervals time of 5 hours, during early and late morning, and late afternoon. Triangulation is not used because this technique is subject to locational errors: operator error during animal movement, electromagnetic interference, distance from the receiver, and effects of different types of vegetation and mapping records (White and Garrott, 1990; Withey et al., 2001; Kauhala and Tiilikainen, 2002). These errors may be unacceptable when the goal is to investigate habitat selection (White and Garrott, 1990).

Species location was recorded as the observer approached the monitored individual. This method was possible to use due to the species territorialism. We considered only those records in which birds were visually detected or their movement among grasses was identified by hearing them.

We delimited a circle of $5 \mathrm{~m}$ radius from the first sighting of a perched bird. We measured the height of the bird on the perch, the total height of the perch, the roost type (tree, shrub or grass), and presence of foliage. The microhabitat variables were (0: 0-20, 1: 21-40, 2: 41-60, 3: 61-80 and 4: 81-100) percentages of exotic and native grasses, percentage exposed soil density and height of shrubs and trees, density of palms (Syagrus petrea and Attalea geraensis) and heterogeneity of vegetation (Wiens, 1969). Collared Crescentchests use armadillo and rat burrows (Kanegae and Reis, 2011); these variables were counted and included in the analysis for this species. We considered trees and shrubs as woody plants with a stem diameter at ground level $\geq 3 \mathrm{~cm}$ and $<3 \mathrm{~cm}$, respectively. The microhabitat data were standardized into categories ranging from 0 to 5 .

Vegetation heterogeneity was obtained using a graduated stick of $1 \mathrm{~m}$ tall subdivided into intervals of $10 \mathrm{~cm}$ (Bibby et al., 2000). Two strings of $10 \mathrm{~m}$ long were used from the centre of the circle to form a perpendicular angle (Wiens, 1974). Three variables of vegetation structure were obtained at the string tips: Het - index of heterogeneity (Wiens, 1969), MaxHeight - range with the maximum vegetation height, and Contact - mean number of vegetation contacts on the stick.

We generated logistic regression models to explain the presence of the species through variables of microhabitat (independent variables). We used a combination of two independent variables due to the limitation in sample size. The best fitted model was obtained by the likelihood with binomial distribution package using Generalized Linear Models (GLM) in R 2.7.1 (R Foundation for Statistical Computing 2008). Model selection was done using Akaike's Information Criterion (AIC, Burnham and Anderson, 2002) with a correction for small samples (AICc) following Hurvich and Tsai (1989). We sorted the best models and evaluated their performance using the AIC weight (wi) and evidence (Burnham and Anderson, 2002). All combinations were analyzed using the Spearman correlation to avoid problems related to multicolinearity. Independent variables with correlation $>60 \%$ were not included in the same model (Zar, 1999).

\section{Results}

Macrohabitat use-Collared Crescentchests used campo cerrado habitat (Table 2). Grassland and wetland areas were used less frequently than expected by chance. The species was not recorded in closed habitats, such as cerrado sensu stricto, cerradão or altered habitat. Species absence also was documented at 20 sampling points in an altered area of USP currently joined to EEI, even using playback.

Microhabitat use - We monitored 20 males of Collared Crescentchests and obtained 1 or 2 visual point records per individual (total of 31 records). The best model selected by the AICc (47.62) to explain bird presence included the highest density of tall $(>1 \mathrm{~m})$ shrubs and native grasses $($ wAIC $=0.568 ;$ Evidence $=1.0)$

We obtained 31 radio-locations of Collared Crescentchest moving on the ground, among clumps of grasses, shrubs, and trees. Ten records of the species singing on perches were obtained. Perches used were trees (mean \pm SD) (eight records, bird height $2.15 \mathrm{~m} \pm 1.64 \mathrm{~m}$; tree height $4.26 \mathrm{~m} \pm 2.29 \mathrm{~m}$ ), and shrubs (two records, bird height $1.05 \mathrm{~m} \pm 0.9 \mathrm{~m}$; shrub height $1.5 \mathrm{~m} \pm 1.4 \mathrm{~m})$.

\section{Discussion}

Macrohabitat use - The Collared Crescentchest only selected areas of campo cerrado. It commonly occurs in

Table 2. Bailey Confidence interval for habitat selection by Collared Crescentchest in EEI, central region of the State of São Paulo. Pi: proportion of actual use of each type of vegetation; (+): used more than expected, (-) used less than expected.

\begin{tabular}{lcccc}
\hline \multicolumn{1}{c}{ Habitat type } & Observed use & Expected use & Bailey interval & Selection \\
\hline Campo limpo and sujo & 0.452 & 0.542 & $0.421 \leq \mathrm{pi} \leq 0.477$ & - \\
Campo cerrado & 0.533 & 0.198 & $0.503 \leq \mathrm{pi} \leq 0.559$ & + \\
Wetland & 0.014 & 0.259 & $0.008 \leq \mathrm{pi} \leq 0.028$ & - \\
\hline
\end{tabular}


grasslands, specifically those with shrubs, but the species used these areas less frequently than expected. Tubelis and Cavalcanti (2000) evaluated the species abundance in central Brazil and had no records in grassland areas, although the species were observed sporadically in shrubby pastures. Moreover, in the same region, the species were more abundant in cerrado sensu stricto and partially disturbed Cerrado (structure similar to campo cerrado). The species were not detected in the cerrado sensu stricto in the present study, an area less representative in the EEI. These variances among regions can be related to differences between other factors such as availability of other habitats, food and density of competitors or predators.

Despite dominance of a disturbed campo cerrado, the Collared Crescentchest was not recorded in USP, an area attached to EEI, even using playback at each sampling point. This indicates the species does not occur in the area, or at least, is very rare. The species move mainly on the ground between clumps of grasses, and the scarcity of these bushes may result in the disappearance of shelters and places for nesting, also affecting the prey availability (insects in the understory). The common occurrence of exotic grass ( $U$. decumbens), and cattle grazing, may have been aggravating factors. Despite the Collared Crescentchest preference for campo cerrado, the species appears to be sensitive to the scarcity of these clumps in the USP area.

Microhabitat use - Collared Crescentchest selected microhabitats characterized by high density of tall ( $>1 \mathrm{~m}$ ) shrubs and native grasses, variables that occur in campo cerrado and campo sujo. Both variables are related to several aspects of the species life history. Tall shrubs are used as perches from which they vocalize for territory defense or sexual selection. Foraging movements (searching for insects) and reproduction occur primarily in the understory, under clumps of grass, palms, and bushes.

These vegetation characteristics can be altered by intense grazing and trampling on by larger herbivores, negatively affecting the Collared Crescentchest occurrence. The presence of cattle in the Cerrado may also change species richness and vegetation structures as consumption can affect leaves, flowers, and seeds of 83 species of plants, belonging to 33 families (Macedo et al., 1978).

Exotic grasses did not inhibit the presence of Collared Crescentchest. However, the preference for native grasses may indicate an adverse indirect relationship as there is competition between grass types in Cerrado (Klink, 1996; Pivello et al., 1999). Tubelis and Cavalcanti (2000) show that the Collared Crescentchest occurs in some altered areas dominated by exotic grasses. This disturbed area is isolated from a preserved area by a road, which could make it difficult for the bird to select high quality habitats. The species may have a low capacity to cross roads due to small wing length and main movement on the ground (MFK pers. obs).

Implications for Management - The Cerrado areas that are intensely farmed may negatively affect the occurrence of the Collared Crescentchest. The species may serve as a bioindicator in that areas of campo cerrado and campo sujo are recovering from intensive grazing and trampling. We suggest that control or removal of exotic grasses and large domestic herbivores would benefit the species distribution.

Collared Crescentchest can occur in areas where both African and native grasses occur, but our study found use of areas with native grasses. The species was regularly recorded in areas of campo cerrado, campo sujo and cerrado sensu sricto and eucalyptus with understory vegetation between 1985 and 1996 at the reserve of the Universidade Federal de São Carlos - UFSCar, located $25 \mathrm{~km}$ North of EEI (Motta-Junior and Vasconcellos, 1996). There was a decrease of about $30 \%$ of the Cerrado in 1994 due to eucalyptus plantations, reducing the area to 21 ha. The species disappeared after that reduction (M. M. Dias Filho and M. R. Francisco, pers. comm.). Small and isolated fragments associated with the dominance of exotic grasses possibly negatively affect bird occurrence. Studies in fragmented areas dominated by African grasses indicated the species' absence and sensitivity to these factors (Motta-Junior and Belentani, 2003; Motta-Junior and Granzinolli, 2004; Motta-Junior et al., 2006). However, these observations need confirmation by studies using a replication of a geographical scale.

Acknowledgements - We would like to thank Jose C. MottaJunior for critically reading a previous version of the manuscript. The Centro Nacional de Pesquisa e Conservação de Aves Silvestres CEMAVE and The Instituto Florestal do Estado de São Paulo (IF) authorized us to study birds. We acknowledge Matheus Reis for the field assistance and CAPES for a doctorate scholarship. MFK would like to thank CNPq for a doctoral grant, Instituto de Biociências da Universidade de São Paulo, Idea Wild, The E. Alexander Bergstrom Memorial Research Award, Neotropical Grassland Conservancy, W. J. and Virginia W. Moorhouse Memorial, Pamela and Alexander F. Skutch, and Birders Exchange for the financial support and equipment donation.

\section{References}

AB'SABER, AN., 1977. Os domínios morfoclimáticos na América do Sul. Geomorfologia, vol. 52, p. 1-21.

BENCKE, GA., MAURÍCIO, GN., DEVELEY, PF. and GOERCK, JM., 2006. Áreas Importantes para a Conservação das Aves no Brasil. São Paulo: Editora SAVE Brasil. 494 p. Parte I - Estados do Domínio da Mata Atlântica.

BIBBY, JC., BURGESS, ND., HILL, DA. and MUSTOE, SH., 2000. Bird Census Techniques. London: The British Trust for Ornithology and The Royal Society for The Protection of Birds.

BLOCK, WM. and BRENNAN, LA., 1993. The habitat concept in ornithology: theory and applications. Current Ornithology, vol. 11, p. 35-91

BURNHAM, KP. and ANDERSON, DR., 2002. Model selection and multimodel inference: a practical information-theoretic approach. New York: Springer.

CANAVELLI, SB., BECHARD, MJ., WOODBRIDGE, B., KOCHERT, MN., MACEDA, JJ. and ZACCAGNINI, ME., 2003. Habitat use by Swainson's Hawks on their austral wintering grounds in Argentina. Journal of Raptor Research, vol. 37, p. 125-134. 
Comitê Brasileiro de Registros Ornitológicos - CBRO, 2011. Lista das aves do Brasil do Comitê Brasileiro de Registros Ornitológicos. Available from: <http://www.cbro.org.br/CBRO/ listabr.htm>. Access in: 24 jun. 2011.

DURIGAN, G., SIQUEIRA, MF. and FRANCO, GADC., 2007. Threats to the Cerrado remnants of the State of São Paulo, Brazil. Scientia Agrícola, vol. 64, p. 355-363.

EITEN, G., 1972. The Cerrado vegetation of Brazil. Botanical Review, vol. 38, p. 201-341. http://dx.doi.org/10.1007/BF02859158

-, 1993. Vegetação do Cerrado. In PINTO, MN. (Org.). Cerrado: caracterização, ocupação e perspectivas. Brasília: Universidade de Brasília. p. 17-73.

GARSHELIS, DL., 2000. Delusions in habitat evaluation: measuring use, selection, and importance. In BOITANI, L. and FULLER, TK. (Eds.). Research Techniques in Animal Ecology: Controversies and Consequences. New York: Columbia University Press. p. 111-164.

GIANOTTI, E., 1988. Composição florística e estrutura fitossociológica da vegetação de Cerrado e mata ciliar da Estação Ecológica de Itirapina (SP). Campinas: Universidade Estadual de Campinas. Dissertação de Mestrado.

GRIFFITHS, R., DOUBLE, M., ORR, KCY. and DAWSON, RJG., 1998. A DNA test to sex most birds. Molecular Ecology, vol. 7, p. 1071-1075. PMid:9711866. http://dx.doi.org/10.1046/ j.1365-294x.1998.00389.x

HURVICH, CM. and TSAI, C., 1989. Regression and time series model selection in small samples. Biometrika, vol. 76, p. 297-307. http://dx.doi.org/10.1093/biomet/76.2.297

HUTTO, RL., 1985. Habitat selection by nonbreeding, migratory land birds. In CODY, ML. (Ed.). Habitat Selection in Birds. New York: Academic Press. p. 455-476.

KANEGAE, MF., 2009. Tamanho populacional, seleção de habitat e área de vida de espécies de aves endêmicas e ameaçadas do Cerrado na Estação Ecológica de Itirapina, São Paulo. São Paulo: Universidade de São Paulo. Tese de Doutorado em Ecologia. Available from: <http://www.teses.usp.br/teses/ disponiveis/41/41134/tde-08072009-104148/>.

-, 2011. Population size of threatened and endemic birds of the Cerrado in Estação Ecológica de Itirapina, a fragmented area in the State of São Paulo, Brazil. Bird Conservation International, vol. 21, p. 1-11. http://dx.doi.org/10.1017/S0959270911000359

KANEGAE, MF. and REIS, M., 2011. Use of burrows by Melanopareia torquata, Collared Crescentchest (Melanopareiidae) in the Cerrado of southeastern Brazil. Revista Brasileira de Ornitologia, vol. 19, p. 398-401.

KANEGAE, MF., TELES, M., LUCENA, SAL. and MOTTA JUNIOR, JC., 2010a. Behavioural and morphological observations of the threatened Collared Crescentchest (Melanopareia torquata) in a Cerrado area from south-east Brazil. Emu, vol. 110, p. 142-145. http://dx.doi.org/10.1071/MU09016

-, 2010b. Note on reproduction of the Collared Crescentchest Melanopareia torquata (Wied) (Bird, Melanopareiidae) in Estação Ecológica de Itirapina, south-east Brazil. The Wilson Journal of Ornithology, vol. 122, p. 162-165.

KAUHALA, K. and TIILIKAINEN, T., 2002. Radio location error and the estimates of home-range size, movements, and habitat use: a simple field test. Annales Zoologici Fennici, vol. 39, p. 317-324.
KENWARD, RE., 2001. A manual for wildlife radio tagging. London: Academic Press.

KLINK, CA., 1996. Germination and seedling establishment of two native and one invading African species in the Brazilian Cerrado. Journal of Tropical Ecology, vol. 12, p. 139-147. http:// dx.doi.org/10.1017/S0266467400009354

KLINK, CA. and MACHADO, RB., 2005. The Conservation of the Brazilian Cerrado. Conservation Biology, vol. 19, p. 707-713. http://dx.doi.org/10.1111/j.1523-1739.2005.00702.x

KÖPPEN, W., 1948. Climatologia. México: Fondo Cultura Economica.

KRABBE, N. and SCHULENBERG, T., 2003. Family RHINOCRYPTIDAE (Tapaculos). In JOSEP, H., ANDREW, E. and DAVID, C. (Eds.). Handbook of the Birds of the World. Barcelona: Lynx Edicions. vol. 8, p. 748-787.

MACEDO, GAR., FERREIRA, MB. and ESCUDER, CJ., 1978. Dieta de Novilhos em Pastagem nativa de Cerrado. Belo Horizonte: Empresa de Pesquisa Agropecuária de Minas Gerais.

MACHADO, RB., RAMOS NETO, MB., PEREIRA, P., CALDAS, E., GONÇALVES, D., SANTOS, N., TABOR, K. and STEININGER, M., 2004. Estimativas de perda da área do Cerrado brasileiro. Brasília: Conservation International do Brasil.

MESQUITA JUNIOR, HN., 1998. Análise temporal com sensor orbital de unidades fisionômicas de cerrado na Gleba Pé-de-Gigante (Campo Estadual de Vassununga-SP). São Paulo: Universidade de São Paulo. Dissertação de Mestrado.

MILLSPAUGH, JJ. and MARZLUFF, JM., 2001. Radio tracking and animal populations. São Francisco: Academic Press.

MOTTA-JUNIOR, JC. and BELENTANI, SCS., 2003. Composição das faunas de aves e mamíferos em seis campos florestais da A.W. Faber-Castell S.A. Triângulo Mineiro. Relatório Final.

MOTTA-JUNIOR, JC. and GRANZINOLLI, MAM., 2004. Ocorrência de aves ameaçadas e endêmicas em fragmentos de cerrado no Estado de São Paulo. In COUTINHO, LM. and DELITTI, WBC. Cerrado. São Paulo: Departamento de Ecologia, Instituto de Biociências, Universidade de São Paulo. CD-ROM.

MOTTA-JUNIOR, JC. and VASCONCELLOS, LAS., 1996. Levantamento das aves do campus da Universidade Federal de São Carlos, estado de São Paulo, Brasil. In Anais do VII Seminário Regional de Ecologia, 1996. Universidade de São Paulo. p. 159-171.

MOTTA-JUNIOR, JC., DEVELEY, PF. and GRANZINOLLI, MAM., 2008. Aves da Estação Ecológica de Itirapina, Estado de São Paulo, Brasil. Biota Neotropica, vol. 8, no. 3. Available from: <www.biotaneotropica.org.br/v8n3/pt/abstract?inventory +bn00308032008>. Acess in: 12 nov. 2010

MOTTA-JUNIOR, JC., GRANZINOLLI, MAM. and BUENO, AA., 2006. Monitoramento das faunas de aves e mamíferos nãovoadores nas áreas de cerrado, mata e florestas de eucalipto no Horto Santa Fé, Brotas, SP. Instituto de Biologia da Conservação Convênio com a International Paper do Brasil.

NEU, CW., BYERS, CR. and PEEK, JM., 1974. A technique for analysis of utilization- availability data. Journal of Wildlife Management, vol. 38, p. 541-545. http://dx.doi.org/10.2307/3800887

OLIVEIRA FILHO, AT. and RATTER, JA., 2002. Vegetation physiognomies and woody flora of the cerrado biome. In OLIVEIRA, PS. and MARQUIS, RJ. (Eds.). The cerrados of Brazil. New York: Columbia University Press. p. 91-120. 
PIVELLO, VR., SHIDA, CN. and MEIRELLES, ST., 1999. Alien grasses in Brazilian savannas: a threat to the biodiversity. Biodiversity and Conservation, vol. 8, p. 1281-1294. http://dx.doi. org/10.1023/A:1008933305857

RIDGELY, RS. and TUDOR, G., 1994. The Birds of South America - The Suboscine Passerine. Oxford: Oxford University Press.

São Paulo. Secretaria do Meio Ambiente - SEMA, 1997. Cerrado: Bases para a conservação e uso sustentável das áreas de cerrado do Estado de São Paulo. São Paulo: Secretaria do Meio Ambiente.

-, 2009. Fauna ameaçada de extinção no Estado de São Paulo. São Paulo: Fundação Campo Zoológico de São Paulo, Secretaria do Meio Ambiente.

SILVA, JMC. and BATES, JM., 2002. Biogeographic patterns and conservation in the South American Cerrado: A tropical savanna hotspot. BioScience, vol. 52, p. 225-233. http://dx.doi. org/10.1641/0006-3568(2002)052[0225:BPACIT]2.0.CO;2

TUBELIS, DP. and CAVALCANTI, RB., 2000. A comparison of bird communities in natural and disturbed non-wetland open habitats in the Cerrado's central region, Brazil. Bird Conservation International, vol. 10, p. 331-350.

WHITE, GC. and GARROT, RA., 1990. Analysis of wildlife radio-tracking data. San Diego: Academic Press.

WIENS, JA., 1969. An approach to the study of ecological relationships among grassland birds. Ornithological Monographs, vol. 8, p. 1-93.

-, 1974. Habitat heterogeneity and avian community structure in North American grasslands. American Midland Naturalist, vol. 91, p. 195-213. http://dx.doi.org/10.2307/2424522

WILLIS, EO., 2004. Birds of a habitat spectrum in the Itirapina savanna, São Paulo, Brazil (1982-2003). Revista Brasileira de Biologia = Brazilian Journal of Biology, vol. 64, p. 901-910. PMid:15744433.

WITHEY, JC., BLOXTON, TD. and MARZLUFF, JM., 2001. Effects of tagging and location error in wildlife radiotelemetry studies. In MILLSPAUGH, JJ. and MARZLUFF, JM. (Eds.). Radio Tracking and Animal Population. San Diego: Academic Press. p. 45-69.

ZAR, JH., 1999. Biostatistical analysis. New Jersey: Prentice Hall. 
